\title{
PENGARUH PEMBERIAN EKSTRAK PAKIS SEBAGAI MOULTING STIMULAN PADA INDUK UDANG WINDU (Penaeus monodon. Fab) DI HATCHERY
}

\author{
Emma Suryati, A. Tenriulo, dan Syarifuddin Tonnek \\ Balai Penelitian dan Pengembangan Budidaya Air Payau \\ Jl. Makmur Dg. Sitakka No 129, Maros 90512, Sulawesi Selatan \\ E-mail:emmasuryati@yahoo.com
}

(Naskah diterima: 21 Maret 2012; Disetujui publikasi: 28 Mei 2013)

\begin{abstract}
ABSTRAK
Tumbuhan pakis (Pteridophyta) merupakan salah satu tumbuhan yang memiliki kandungan senyawa steroid yaitu fitoekdisteroid dalam bentuk 20-Hydroxyecdyson atau Ecdysteron berfungsi sebagai molting stimulan pada krustase. Pada umumnya ecdysteron ditemukan pada krustase baik yang ada di darat maupun yang berada di dalam air seperti kepiting, udang, dan krustase lainnya yang ditemukan secara alami dan berfungsi sebagai pengatur proses penggantian kulit dan mengontrol pembentukan exoskeleton baru untuk menggantikan exoskeleton yang lama. Selain ablasi proses moulting pada udang dapat diinduksi melalui penambahan 20-hydroksi ecdysteron (20 E) pada hemolim sehingga fase premolting dapat diatur sesuai dengan kebutuhan. 20-hydroksiecdysteron dapat diperoleh dari ekstrak tumbuhan diantaranya bayam, asparagus, pakis, dan lain-lain melalui pemisahan dengan ekstraksi, fraksinasi, dan pemurnian dengan HPLC dilanjutkan dengan elusidasi struktur. Pemberian ekstrak pakis pada induk udang windu untuk memacu terjadinya pergantian kulit dilakukan melalui dengan beberapa konsentrasi menggunakan disain Rancangan Acak Lengkap (RAL). Hasil analisis memperlihatkan bahwa kandungan phytoecdysteron pada pakis perkisar $230-730 \mathrm{mg} / \mathrm{L}$ dari larutan ekstrak yang setara dengan $20 \mathrm{~g}$ bahan segar. Konsentrasi ECD $25 \mathrm{mg} / \mathrm{L}$, memperlihatkan respon yang paling baik sebagai moulting stimulan.
\end{abstract}

KATA KUNCI: Ekstrak pakis, moulting stimulan, induk udang

\section{ABSTRACT: Giving effectc of fern extract as parent moulting stimulant on tiger shrimp parent (Penaeus monodon) Feb in hatchery. By: Emma Suryati, A. Tenriulo, and Syarifuddin Tonnek}

Fern (Pteridophytes) is one of plant containing steroid compound identified as phytoecdysteroid forming 20-hydroxyecdysone. This compound has a function as moulting stimulant to crustaceae. Generally, ecdysteron was found in crustaceae not only in teresterial but also in water environment such as, crab, shrimp and other crustaceans naturally found. The ecdysteron has a function as moulting regulator and controller of forming of new exosceleton to replace the old exosceleton. Beside ablation, moulting process in shrimp can be inducted by adding 20hydroxyecdysterone (20E) in hemolymp causing premoulting phase can be adjustable according to requirement. 20-hydroxyecdysterone (20E) can be isolated from plant extract such as spinach, asparaguse, fern and so on by separating process such as extraction, fractination, and purifying by HPLC continued by structure elusidation. The giving of fern extract to the broad stock of tiger shrimp to stimulante the occuring 
of moulting is done with several concentration by using Complete Random Design (RAL). The result of analysis show that phytoecdysteron content on fern extract range $230-730 \mathrm{mg} / \mathrm{L}$ be equal with $20 \mathrm{~g}$ fresh material. ECD concentration of $25 \mathrm{mg} /$ $L$, showed the best response as moulting stimulant.

\section{KEYWORDS: fern extract, moulting stimulant, tiger shrimp}

\section{PENDAHULUAN}

Permasalahan yang sering dijumpai pada pengelolaan induk udang windu (Penaeus monodon. Fab), antara lain proses pergatian kulit pada induk betina tidak bersamaan sehingga tidak dapat terjadi perkawinan dan menyebabkan kegagalan dalam proses reproduksi. Teknik ablasi atau pemotongan tangkai mata biasa digunakan di hatchery untuk memacu pematangan gonad dan pergantian kulit. Udang windu ( $P$. monodon) memiliki organ $X$ yang terletak pada tangkai mata, organ ini dapat menghasilkan Gonad Inhibiting Hormone (GIH) yang berfungsi menghambat perkembangan ovarium dan menghambat aktivitas organ $Y$, dan melalui pemotongan tangkai mata, maka organ $X$ sebagai penghasil GIH akan hilang dan menyebabkan kandungan $\mathrm{GIH}$ pada hemolimp menurun, sehingga organ $Y$ dapat menghasilkan Gonad Stimulating Hormone (GSH) dan merangsang terjadinya proses vitelogenesis. Namun demikian masih banyak masalah seperti pembusukan telur yang disebabkan oleh mikroorganisme yang menempel, serta infeksi pada luka bekas sayatan, serta kualitas dan kuantitas larva dari waktu ke waktu mengalami penurunan (Aktas \& Kumlu, 1999). Induk yang telah kehilangan satu mata sering ditemukan tidak dapat bertelur, bahkan mengalami penurunan daya kekebalan tubuh, sehingga mudah terserang penyakit. Akibatnya induk-induk ini hanya sekali bertelur sepanjang hidupnya (Anggoro, 2001).

Selain ablasi, proses moulting pada udang dapat dilakukan melalui induksi dengan penambahan 20-hydroksi ecdysteron (20 E) pada hemolim sehingga fase premolting dapat diatur sesuai dengan kebutuhan. Dengan diketahui titer ecdystron pada proses molting pada udang, maka proses ganti kulit dapat diatur melalui induksi ecdysteron pada hemolin udang (Gunamalai et al., 2006). Ecdysteron pada umumnya ditemukan pada krustase baik yang ada di darat maupun yang berada di dalam air seperti kepiting, udang dan krustase lainnya yang ditemukan secara alami dan berfungsi sebagai pengatur proses penggantian kulit dan mengontrol pembentukan exoskeleton baru untuk menggantikan exoskeleton yang lama. Selain terdapat pada krustase, ecdysteron juga dapat dijumpai pada beberapa jenis tanaman yang sering dimanfaatkan oleh krustase, di alam seperti murbei (Morus alba) yang biasa digunakan sebagai makanan ulat sutra dan memacu ulat tersebut menjadi kepompong, serta beberapa tanaman lain yang termasuk golongan Amaranthus sp., asparagus, serta jenis paku-pakuan yang banyak tumbuh di daerah tropis seperti Indonesia.

Pakis raja (Cycas revoluta Thumb) merupakan tanaman yang berbentuk pohon seperti palem, tinggi sampai $6 \mathrm{~m}$, kadangkadang bercabang. Daun penuh melingkar di ujung, menyirip, panjang sampai $2.5 \mathrm{~m}$ dan 50 150 pasang daun pinak. Bunga menyatu dalam cone, cone betina pada ujung dengan banyak karpofil, panjang mencapai $50 \mathrm{~cm}$. Biji membulat telur-menjorong, berwarna oranye. Penyebarannya luas dari India, Sri Lanka, ke Asia Tenggara termasuk Indonesia, kemudian ke Australia, Mikronesia, seringkali hidup di sepanjang pantai dan hutan-hutan dataran rendah dan sering didapati sebagai tanaman hias yang banyak digemari oleh masyarakat (Stennis, 1981). Daun dan bunga Cycas revoluta mengandung saponin, flavonoida, tanin, dan turunan steroid yang sering digunakan dalam pengobatan tradisional.

Dari informasi yang ada, kandungan ecdysteron yang terdapat pada tumbuhan seperti pakis, dapat diisolasi dan diidentifikasi melalui proses ekstraksi, fraksinasi, pemurnian senyawa serta elusidasi struktur (Harborn, 1973). Senyawa ini diharapkan dapat menggantikan atau substitusi ecdysteron yang berasal dari krustase yang relatif mahal. Isolat ecdysteron dari tumbuhan mudah diperoleh dan relatif lebih murah untuk membantu proses reproduksi dan pergantian kulit pada induk udang di hatchery. 
Untuk mengetahui konsentrasi dan jenis ecdysteron yang terdapat di dalam pakis raja (Cycas revoluta. Thumb) serta dosis yang tepat untuk memacu terjadinya moulting, maka perlu dilakukan isolasi, identifikasi, ellusidasi struktur, serta cara dan penentuan dosis ecdysteron yang tepat untuk memacu terjadinya molting pada induk udang windu.

\section{BAHAN DAN METODE}

Penelitian ini terdiri atas dua tahapan pekerjaan yaitu isolasi dan identifikasi kandungan ecdysteron pada tumbuhan pakis, kemudian penentuan cara dan dosis ekstrak pakis yang dapat memacu terjadinya pergantian kulit pada induk udang windu di hatchery.

Tanaman pakis (Cycas revoluta Thumb) diambil bagian daunnya. Daun tanaman pakis dikumpulkan lalu dikering anginkan pada suhu $30^{\circ} \mathrm{C}$.

\section{Isolasi dan pemurnian ekstrak pakis}

Isolasi dan pemurnian ecdisteroid dari tanaman pakis dilakukan dengan cara ekstraksi tanaman pakis kurang lebih $200 \mathrm{~g}$, dimaserasi menggunakan pelarut methanol $80 \%$ sebanyak $200 \mathrm{~mL}$ untuk mendapatkan ekstrak kasar. Selanjutnya pemurnian ecdysteron diperoleh dari ekstrak methanol ditambah dengan acetone $1 / 2$ bagian, 1 bagian, dan 2 bagian. Ekstrak yang diperoleh kemudian dikisatkan hingga volume $10-20 \mathrm{~mL}$, fraksioanasi menggunakan campuran pelarut $\mathrm{n}$-hexan dan methanol $50 \%$ dengan perbandingan $1: 2$, diulangi 3 kali. ekstrak methanol yang diperolah, dikisatkan kemudian ditambahkan alumina hingga kering, kemudian dielusi menggunakan campuran diklormetan dan etanol dengan beberapa perbandingan yaitu; 95:5, 90:10, dan 80:20. hingga diperoleh 3 fraksi. Uji kemurnian dan penentuan jumlah ecdysteron dilakukan menggunakan HPLC menggunakan fasa cair campuran metanol dan air dengan perbandingan 85:15, dan fasa diam $\mathrm{C}_{18} \mathrm{RP}$ (Munson, 1984).

Analisis kandungan ecdisteroid pada tanaman pakis dilakukan dengan elusidasi struktur dan identifikasi ecdisterol diperoleh dari isolat murni pada tahapan isolasi dan pemurnian, diidentifikasi menggunakan reaksi penampak noda pada kromatografi lapis tipis untuk menentukan golongan dan sifat ecdisteroid yang diperoleh, pengukuran panjang gelombang pada sinar ultra lembayung dan spektrum infra merah untuk menentukan gugus fungsi, selanjutnya pengukuran berat molekul dan struktur menggunakan GCMS (Munson, 1984).

\section{Pengambilan sampel udang windu dan penentuan analisis}

Hewan uji yang digunakan untuk percobaan adalah induk udang windu yang berasal dari tambak dari Kab, Selayar dengan ukuran kurang lebih $100 \mathrm{~g} /$ ekor. Pengukuran kandungan ecdysteron pada setiap fase moulting pada udang diukur melalui pengambilan hemolim udang kurang lebih $1 \mathrm{~mL}$, kemudian diekstraksi menggunakan pelarut organik dan diukur menggunakan HPLC dengan kolom $\mathrm{C} 18$ dengan fasa terbalik, dan fasa gerak campuran metanol dengan air dengan perbandingan 85:15.

Pemberian ekstrak pakis disesuaikan dengan kandungan ecdysteron yang terukur dari setiap fase moulting. Penyuntikan dilakukan pada segmen kedua udang windu. Pemeliharaan dilakukan pada bak induk yang dilengkapi dengan aerasi dan pemberian pakan cumi dan kerang. Pengamatan dilakukan terhadap perubahan dan pergantian kulit serta ciri-ciri morfologi udang, kondisi lingkungan antara lain kualitas air media pemeliharaan, serta nutrisi dan pakan yang diberikan pada udang.

Persentase moulting dihitung berdasarkan jumlah udang yang moulting dibagi dengan jumlah udang yang diberi perlakuan kali $100 \%$. Masa laten moulting adalah waktu yang dibutuhkan sejak perlakuan ekstrak pakis hingga terjadi moulting pada udang windu yang diuji. Mortalitas dihitung dengan membandingkan jumlah udang yang mati dibagi dengan jumlah udang yang diberi perlakuan kali $100 \%$.

\section{Rancangan}

Penelitian dilakukan dengan pendekatan secara deskriptif dan pendekatan secara eksperimental menggunakan rancangan acak lengkap (RAL) sebagai perlakuan adalah dosis ecdysteron yang digunakan antara lain 0,25 , 50,75 , dan $100 \mathrm{mg} / \mathrm{L}$ dengan 5 kali ulangan, menggunakan 10 ekor induk dari setiap perlakuan.

Pendekatan secara deskriptif digunakan pada awal dari rangkaian percobaan antara lain 
penentuan kisaran dosis ecdysteron selama fase-fase moulting hingga berakhirnya moulting, hingga diketahui kisaran dosis yang dibutuhkan untuk memacu terjadinya moulting pada induk udang.

\section{HASIL DAN BAHASAN}

a. Isolasi dan identifikasi kandugan ecdysteron pada daun tanaman pakis raja (Cycas revoluta Thumb)

Hasil isolasi Edcysteron (ECD) pada tanaman pakis raja memperlihatkan kandungan ecdysteron terdapat pada ketiga fraksi, yatu fraksi 1, 2, dan 3 dan kandungan ECD yang paling tinggi terdapat pada fraksi ke-3 hingga mencapai rata-rata $726 \mathrm{mg} / \mathrm{L}$ dalam larutan setara dengan dua puluh gram berat segar, sehingga dalam $1 \mathrm{~g}$ tanaman mengandung $36,347 \mathrm{mg} / \mathrm{L}$ ecdysteron.

Uji kemurnian menggunakan HPLC dengan fasa diam C18, dengan fasa gerak campuran metanol air dengan perbandingan 85:15. Pada kromatogram terlihat satu puncak yang dominan, hal ini menunjukkan bahwa senyawa yang terisolasi adalah senyawa yang tunggal dan hampir murni. Gambar kromatogram dari isolat Ecdysteron pada tanaman pakis raja dapat dilihat pada Gambar 3.

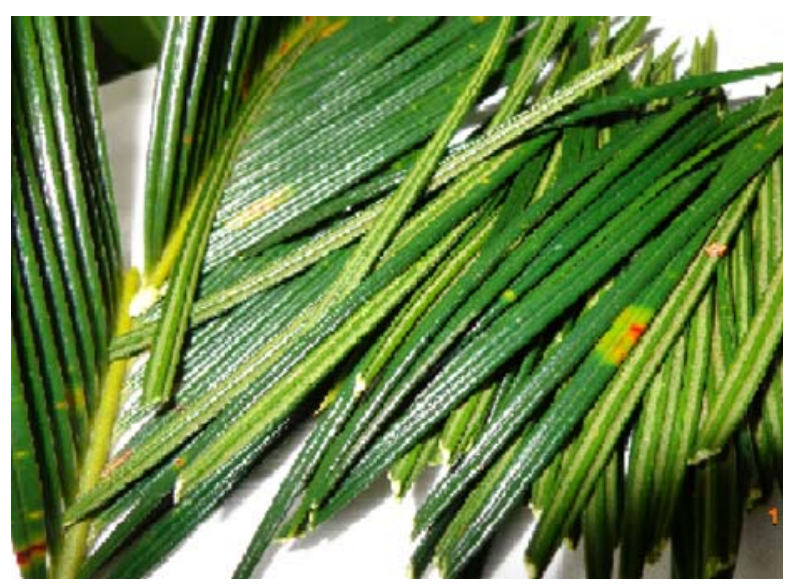

Gambar 1. Daun Pakis raja (Cycas revoluta Thumb)

Figure 1. King fern leaf (Cycas revoluta Thumb)

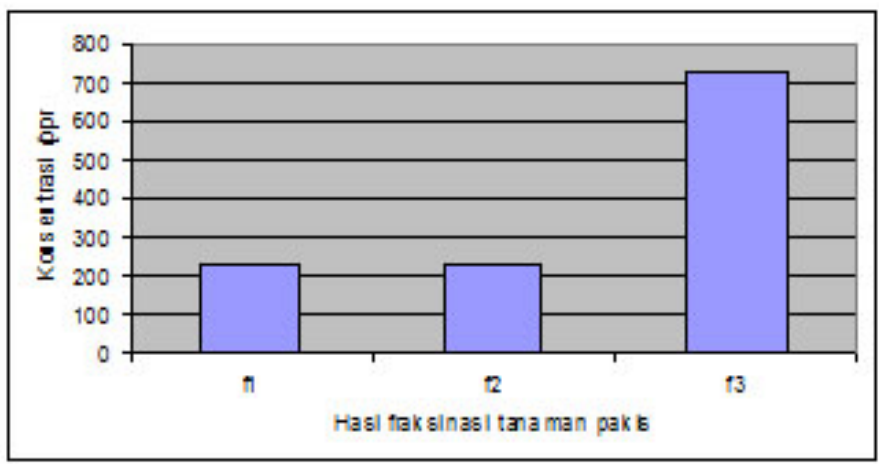

Gambar2. Konsentrasi ECD pada tanaman pakis setelah difraksinasi

Figure 2. ECD concentrations in the fern after fractionated 


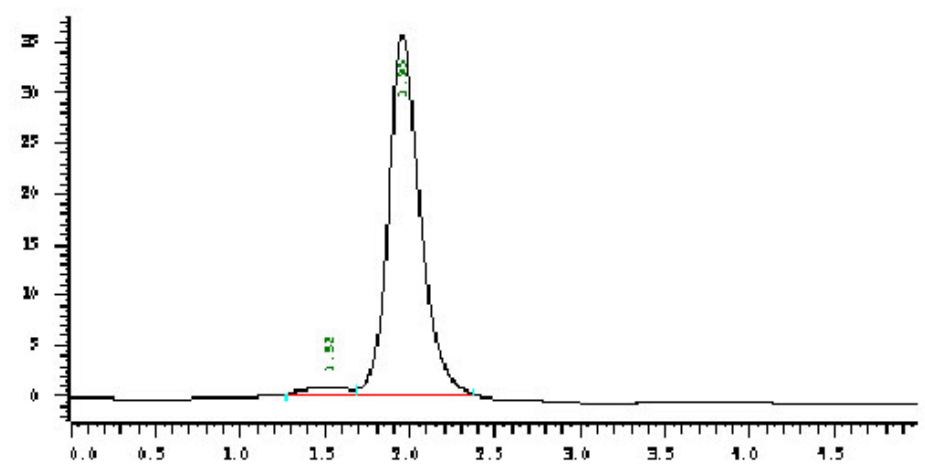

Gambar 3. Kromatogram Isolat Ecdysteron pada tanaman pakis raja (Cycas revolutaThum)

Figure 3. Chromatograms of isolates Ecdysteron the king fern (Cycas revoluta Thumb)

Selanjutnya pengukuran ECD pada tanaman pakis raja dilakukan berdasarkan pengukuran luas area pada kromatogram menggunakan standar 20-hydroxyecdysone, gambar kurva kalibrasi dapat dilihat pada Gambar 4.
Hasil pengukuran panjang gelombang UVVis isolat ecdysteron pada tanaman pakis raja (Cycas revoluta) Thum, memperlihatkan ada dua puncak yang dominan, hal ini memberikan gambaran bahwa senyawa tersebut memiliki dua ikatan rangkap yang terkonyugasi. Gambar spektrum UV-Vis dapat dilihat pada Gambar 5.

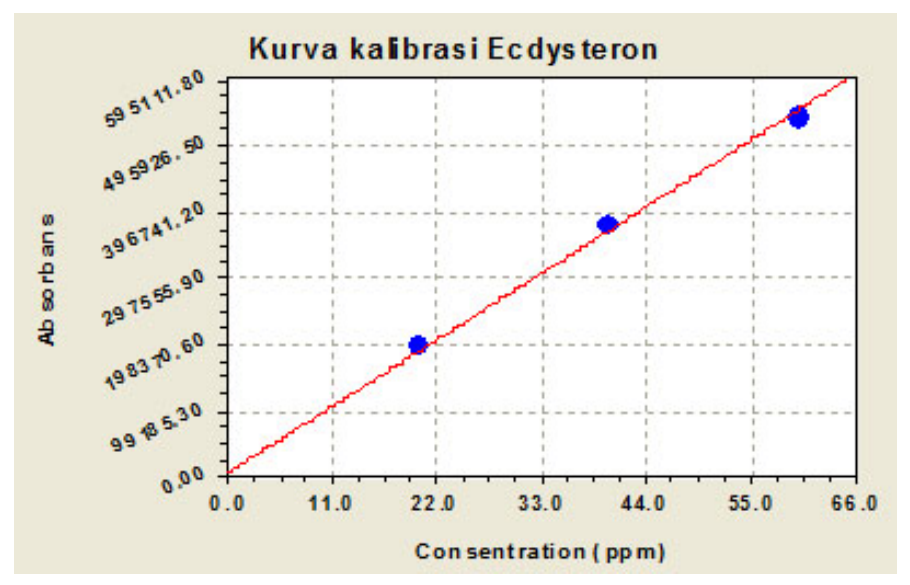

Gambar 4. Kurva kalibrasi pengukuran Ecdysteron pada tanaman pakis raja (Cycas revoluta) Thum

Figure 4. The calibration curve measurements Ecdysteron the king fern (Cycas revoluta) Thum 


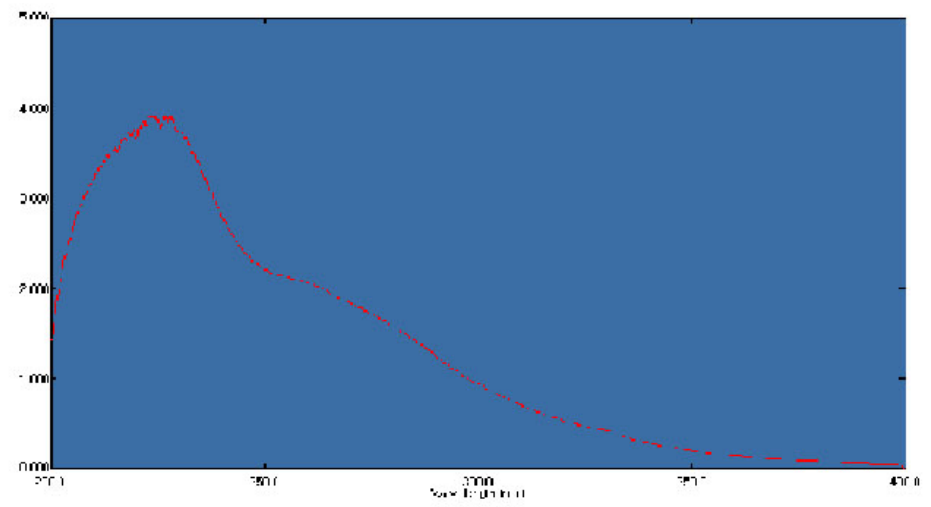

Gambar 5. Spektrum UV-Vis isolat ECD pada tanaman pakis raja (Cycas revoluta Thum)

Figure 5. UV-Vis spectrum ECD isolates the king fern (Cycas revoluta Thum)

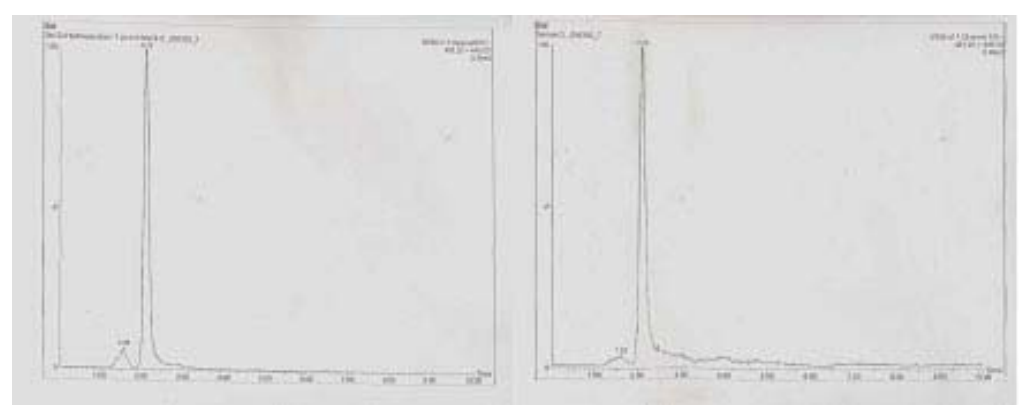

Gambar 6. Kromatogram LC-MS isolat ECD standard (A) dan ECD dari tanaman pakis (Cycas revoluta Thum) (B)

Figure 6. LC-MS chromatograms standard ECD isolates $(A)$ and ECD of fern plants (Cycas revoluta Thum) (B)

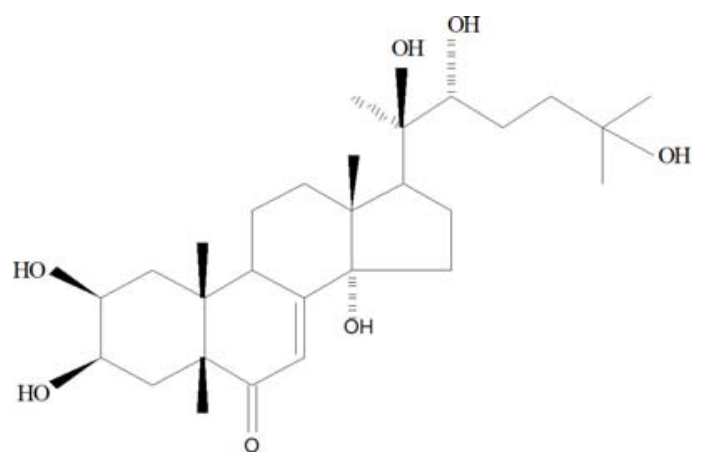

Gambar 7. Struktur molekul senyawa Ecdysteron pada pakis raja (Cycas revoluta Thumb)

Figure 7. The molecular structure of compounds Ecdysteron the king fern (Cycas revoluta Thumb) 


\section{Aplikasi pemberian Ecdysteron pada udang windu (Penaeus monodon)} Fab.

Induk udang yang digunakan adalah induk udang windu (P.monodon) 10 ekor untuk setiap perlakuan dengan ukuran dan berat udang berkisar pada 65-140 g dengan rataan $78,6 \mathrm{~g}$, sedangkan panjang udang berkisar $18-24 \mathrm{~cm}$ dengan rataan $19,42 \mathrm{~cm}$. Titer ecdysteron pada hemolim udang berkisar $27,8-66,13 \mathrm{mg} /$ L dengan rataan $45,32 \mathrm{mg} / \mathrm{L}$. Perlakuan pemberian ecdyteron pada udang dilkukan berdasarkan titer hemolim pada udang tersebut yaitu $0,25,50,75$, dan $100 \mathrm{mg} / \mathrm{L}$ melalui penyuntikan.

Hasil aplikasi penyuntikan ECD yang diisolasi pakis raja terhadap induk udang windu pada konsentrasi $25 \mathrm{mg} / \mathrm{L}$ dapat mempercepat terjadinya molting pada jam ke12 sebanyak $66 \%$, 33\% pada konsentrasi 50 $\mathrm{mg} / \mathrm{L}$, dan masing-masing $20 \%$ pada $75 \mathrm{mg} / \mathrm{L}$ dan $100 \mathrm{mg} / \mathrm{L}$ dan pada jam ke-48 (Gambar 8). Hasil uji statistik memperlihatkan perbedaan yang nyata pada perlakuan $25 \mathrm{mg} / \mathrm{L}$ dengan perlakuan lainnya, sedangkan perlakuan 50 , 75, dan $100 \mathrm{mg} / \mathrm{L}$ tidak memberikan perbedaan yang nyata. Kondisi induk udang setelah moulting menjadi lebih sehat dan gesit.
Moulting adalah proses pergantian cangkang pada udang (crustacea) dan terjadi ketika ukuran daging udang bertambah besar sementara eksoskeleton tidak bertambah besar karena eksoskeleton bersifat kaku, sehingga untuk menyesuaikan keadaan ini udang akan melepaskan eksoskeleton lama dan membentuk kembali dengan bantuan kalsium. Semakin baik pertumbuhannya semakin sering udang berganti cangkang. Inilah yang kemudian dikenal sebagai pertumbuhan.

Secara umum, frekuensi pergantian cangkang akan selalu beriringan dengan pertambahan umur, pada yuwana terjadi setiap 10 hari, sedangkan setelah dewasa terjadi 4-5 kali setahun, ketika sudah menjadi induk dan pernah memijah biasanya melakukan moulting 1-2 kali setahun.

Ada 2 faktor yang mempengaruhi moulting pada krustasea yaitu faktor eksternal dan faktor internal. Faktor eksternal di antaranya; adanya stressor, nutrisi, photoperiod, dan temperatur sedangkan faktor internal terkait dengan produksi hormon ekdisteroid dan Molt Inhibiting Hormon (MIH). Pelepasan hormon ekdisteroid oleh organ-Y yang bervariasi berdasarkan stadium yang dilaluinya dalam siklus ganti kulit dan juga tergantung pada

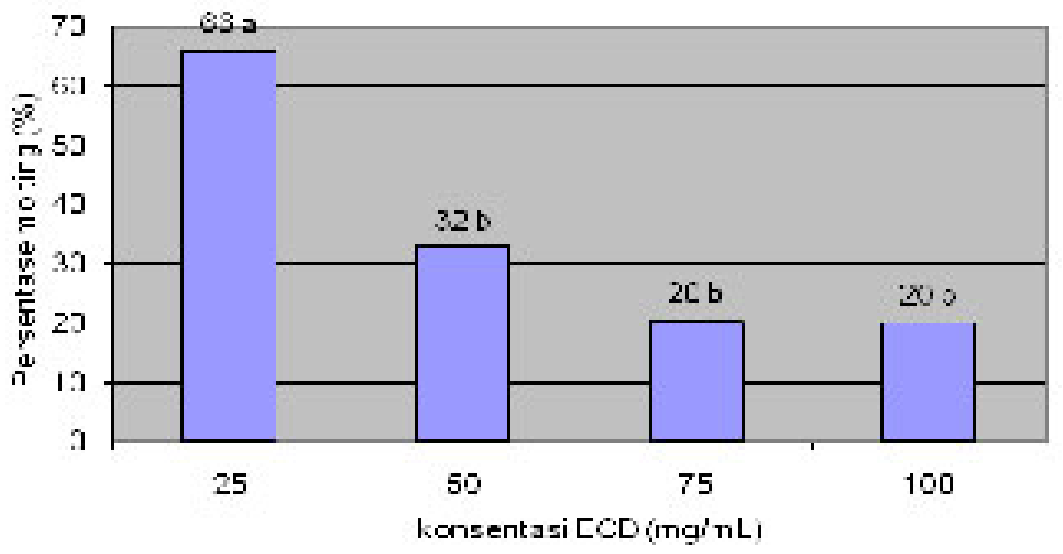

Keterangan:Nilai yang diikuti huruf yang sama pada setiap kolom menunjukkan perbedaan yang tidak nyata $(P>0,05)$

Note:The similiar alfabeth in one column and one line is not significantlly different $(P>0.05)$

Gambar 8. Persentase induk udang yang moulting setelah pemberian ECD

Figure 8. Percentage holding after the moulting shrimp ECD 


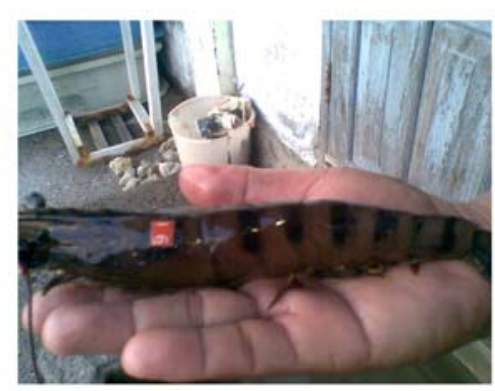

(A)

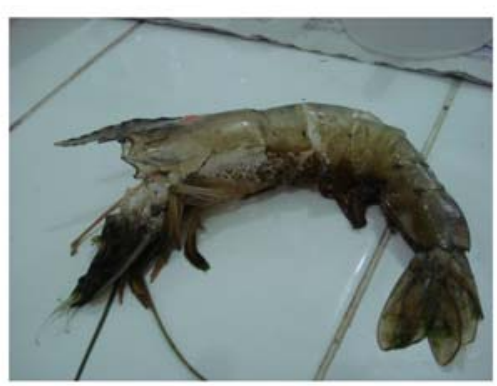

(B)

Gambar 9. Induk udang windu ( $P$. monodon) sebelum moulting (A) dan sesudah moulting (B)

Figure 9. Parent tiger shrimp (P. monodon) before moulting $(A)$ and after molting (B)

kadar hormon ekdisteroid yang terdapat dalam hemolim.

Pengaturan kadar hormon ekdisteroid hemolim dapat dipengaruhi melalui beberapa lintasan. Penelitian terhadap organ-Y dengan cara in vitro memperlihatkan bahwa ekstrak tangkai mata dapat memperlambat atau menghentikan pelepasan hormon ekdisteroid. Berdasarkan sistem pengaturan kadar hormon ekdisteroid hemolim tersebut diatas dan hubungannya dengan MIH. Model sistem pengaturan neuroendokrin yang pernah diketahui adalah interaksi antara organ-X kelenjar sinus dan organ-Y. Faktor lingkungan termasuk di dalamnya stres akan mengaktifkan neuron serotonergik tangkai mata yang merangsang kompleks sel-sel neurosekretori organ-X (XO) - kelenjar sinus (SG) untuk melepaskan MIH. MIH dalam hemolim berikatan dengan permukaan reseptor sel organ-Y yang menyebabkan adenilat siklase (AC) aktif dan mengubah ATP menjadi cAMP (siklik AMP). Produksi hormon ekdison dari kolestrol akan ditekan oleh cAMP. Pengaruh yang berlawanan ditimbulkan oleh kalsium (Ca) yang berikatan dengan kamodulin akan mengaktifkan enzim cAMP-fosfodiesterase membentuk 5 AMP, sehingga produksi ekdison dapat ditingkatkan kembali. Kenaikan kadar kalsium hemolim pada awal ganti kulit dan akan turun kembali pada saat ganti kulit, keadaan ini berhubungan dengan perubahan ekdisteroid hemolim.

Pada pemberian ekstrak pakis dengan konsentrasi $25 \mathrm{mg} / \mathrm{L}$ memperlihatkan persentasi molting yang paling tinggi dibandingkan dengan konsentrasi diatasnya hal ini disebabkan karena di dalam induk udangnya sendiri sudah memiliki kandungan ecdysteron yang cukup, sehingga dengan memacu sedikit saja sudah mampu menstimulan molting pada induk udang, sedangkan pada konsentrasi yang lebih tinggi dapat mengakibatkan terjadinya penumpukan ecdysteron pada jaringan udang dan pabila konsentrasinya melebihi kebutuhan molting maka akan menghambat terjadinya moulting.

\section{KESIMPULAN}

1. Ecdysteron pada daun tanaman pakis dapat diisolasi melalui ekstraksi fraksinasi dan pemurnian dengan kromatografi kolom.

2. Kandungan Ecdysteron pada pakis berkisar antara 230-730 mg/L pada larutan ekstrak setara dengan $20 \mathrm{~g}$ berat segar.

3. Konsentrasi yang paling baik sebagai moulting stimulan pada induk udang windu yaitu pada konsentrasi ECD 25 mg/L.

\section{DAFTAR ACUAN}

Anggoro, S. 2001 . Udang Ablasi Mata Indonesia Ditolak Konsumen Amerika. Publish : 5 April 2001. Sumber http:// www.kompas.com

Aktas, M. \& Kumlu, M. 2004. Gonadal Maturation and Spawning in Penaeus semisulcatus de Hann, 1844 by Hormone Injection. Mustafa Kemal University, Faculty of Fisheries, Hatay-TURKEY. 
Chang, E.S., Hertz, W.A., \& Prestwich, G.D. 1992. Reproductive endocrinology of the shrimp Sicyonia ingentis: steroid, peptide, and terpenoid hormones. NOAA Tech. Rep. N MFS, 106: 1-6.

Dall, W. 2004. Studies on the physiology of a shrimp, Metapenaeus sp. (Crustacea: Decapoda: Penaeidae). II. Endocrines and control of moulting. Australian Journal of Marine and Freshwater Research, 16(1): 112.

Gunamalai, V., Kirubagaran, R., \& Subramonian, T. 2003. Sequestration of ecdysteroid hormone into the ovary of the mole crab, emerita asiatica (Milne edward). Current science, 85(4): 493-496.

Gunamalai, Kirubagaran, R., \& Subramoniam, T. 2006. Vertebrate steroids and the control of female reproduction in two decapod crustaceans, Emerita asiatica and
Macrobrachium rosenbergii . CURRENT SCIENCE, VOL. 90, NO. 1.

Harborn, J.D. 1973. Phytochemical Methods. Chapman and Hill London, 354 pp.

Munson, J.W. 1984. Pharmaceutical Analysis Modern Methode. Part B. Marcel Dekker. Inc. The Upjohn Company. Kalamazoo, Michigan, $417 \mathrm{pp}$.

Okumura \& Sakiyama. 2005. Hemolymph levels of vertebrate-type steroid hormones in female kuruma prawn arsupenaeus japonicus (Crustacea: Decapoda: Penaeidae) during natural reproductive cycle and induced ovarian development by eyestalk ablation Fisheries Science, Volume 70, Number 3, p. 372-380 (9).

Pei-Li Gu, Chu, K.H., \& Chan S.M. 2004. Bacterial expression of the shrimp molt-inhibiting hormone (MIH) (Abstract). Journal Cell and Tissue Reserch. 